\title{
Are Indonesian Girls Okay? \\ An Examination of The Discourse of Child Marriage, Victimization, and Humanitarian Visuality of Global South Girls
}

\author{
Annisa R. Beta, Ryan Febrianto \\ The University of Melbourne | Center on Child Protection and Wellbeing at \\ Universitas Indonesia (PUSKAPA) \\ annisa.beta@unimelb.edu.au | ryanfebrianto@puskapa.org
}

\begin{abstract}
The discourse of child marriage in relation to the lives of the girls in Indonesia specifically and the Global South generally is often limited to describing their vulnerability and position as victims. Practices of child marriage are inseparable from its exploitative and harmful nature. This paper, however, shows that the discourse of child marriage produced in humanitarian projects and interventions often avoids the complexity and diversity of the practices and the lives of the girls and reduces the problem into monolithic narrative of their communities' traditions, backwardness, and inherent gender inequality. This paper asks: How has the discourse of child marriage in relation to Indonesian girls developed historically? How have international NGOs depicted the issue of child marriage? We show that child marriage discourse is historically rooted in colonial ideas surrounding modernity, childhood, and marriage, and that documents published by international NGOs tend to flatten the complex experiences and lives of Indonesian girls.
\end{abstract}

KEYWORDS: Child Marriage | Indonesian Girls | Global South | Humanitarian Visuality

\section{PREFACE}

Regulating the marital age has been prominent in the discourse surrounding child marriage. The international human rights frameworks, such as CEDAW Committee (1994) and the Committee on the Rights of the Child (2003) state that the minimum age of marriage should be 18 years old, constituting marriages under the age of 18 as a violation of child rights to education, health, and wellbeing. A number of international humanitarian organizations and initiatives--such as Girls Not Brides, Plan International, and Global Citizen, among others--also deploy child marriage prevention as part of the protection of women's human rights, especially girls'. At the global discursive level, defining child marriage is often intertwined with the idea of 'forced marriage', which involves the marriage between an early-teenage girl and a much older man. As such, the discourse of early, child, or forced mar- riage (hereafter child marriage) particularly in relation to the lives of girls living in the Global South often places them as vulnerable, 'victims' that need saving from 'harmful' norms (Horii 2020). Practices of child marriage are inseparable from its exploitative and harmful nature. However, as we will show in this paper, the discourse of child marriage produced in humanitarian projects and interventions often avoids the complexity and diversity of the practices and the lives of the girls and reduces the problem into a monolithic narrative of Global South communities' traditions, backwardness, and inherent gender inequality.

We ask: How has the discourse of child marriage in relation to girls in the Global South, especially Indonesian girls, developed historically? At the present time, how have international NGOs de- 
picted the issue of child marriage? To answer these questions, the paper will start with an overview of literature on girl-centred development agendas. ${ }^{1} \mathrm{We}$ then proceed to our research methods. The following sections shared our findings based on the historical and present discourse of child marriage in Indonesia. We end the paper with our reflections and recommendations on how the issue of child marriage can be discussed beyond the narratives of victimization to celebrate Indonesian and Global South girls' agency.

\section{GIRL-CENTRED DEVELOPMENT AGENDAS}

This paper is informed by feminist literature critical of the political, social, and cultural consequences of development discourses that focus on empowering girls and deploying ideas of 'girl power'. In many development initiatives, girls are considered as better investment because they are perceived to be more responsible than boys and have relatively more freedom than older women (Koffman and Gill 2013); they are more productive as they work harder and spend less resources on themselves (Wilson 2015); and they are also more likely to give back to the community (Calkin 2015b; Cobbett 2014).

In development empowerment agendas, girls are seen to be the ideal neoliberal subjects who are central in the labor force and the market. Neoliberal values are evident in at least four development agendas: access to the labor market, promotion of entrepreneurship and microfinancing programs, freedom of consumption, and--the focus of this paper-- reproductive rights and choice (Calkin 2015a; Harris 2004; Hickel 2014; Wilson 2015). The agendas of empowerment, in other words, seem to equate giving voice or power to girls with economic capital and productivity. We briefly explain each agenda below.

Development initiatives see girls' access to means of production as key to their empowerment; therefore, making sure they have the opportunity to join the labour forces is assumed to be effective in improving girls' lives as well as their community's and the global economy (Hickel 2014). However, increasing participation of girls in labour forces does not necessarily guarantee them a living wage, equal pay to their male counterparts, or protection from exploitation. Jason Hickel notes that international development agencies risk young women's lives into new forms of subservience as workers, consumers and debtors. He points out that the agencies make "heavy use of Marxist and feminist language, critiquing the fact that women lack access to means of production (like land and capital), critiquing culture as ideology wielded by males to control and subordinate females, and adopting the language of liberatory 'social movements" to justify economic-centred empowerment model (2014:1362-63).

Girls are also assumed to be the source of 'untapped' entrepreneurship potential. They are considered to be already entrepreneurial due to their 'maternal' nature (Calkin 2015a:301), and girls who live in poverty are presumed to be easily stimulated by entrepreneurial programmes (Koffman and Gill 2013:85). Kalpana Wilson points to how in Bangladesh microfinance-as-empowerment programmes prefer women and girls because they are stereotypically more responsible and have shame and honour' which can be a collateral that prevents them from running away from the programmes (2015:811). Some girl empowerment organizations aim to build girls' confidence by promoting a figure of what Sarah Banet-Weiser calls the entrepreneur of the self' who concentrates on individual self-work: building confidence and leadership capacity and celebrating beauty (2015:186). Similarly, Anita Harris has identified programs that aim to build young women's economic autonomy by developing business ideas and plans (2004). The underlying tenet of such entrepreneurship schemes is the construction of young women as the ideal subject of late capitalism or 'the girl entrepreneur' who makes their own success and is responsible for her own social rights (2004:71-74).

In addition to girls' participation in the labour force and developing entrepreneurial capacity, the freedom to make personal choices as consumers is included in girls' empowerment discourse. 'Girl power' is commodified for the consumption of young 
women through well-packaged social activism--they are key to the 'market of empowerment': a market that promotes the necessity for girls to be empowered and consume their empowerment (BanetWeiser 2015:183). In the lifestyle industry, products, brands, and lines are marketed using the terminology of 'girl power', and the image of assertive, smart, and sassy girlhood is central. The ideal future is for the girls to grow up to be educated and successful career women with glamorous lifestyles. Girls therefore need the necessary training and assistance to pursue that future. In effect, girls can be categorized into at least two: the 'can-do girls' and the 'at-risk girls', based on their capacity to attain the ideal future as they grow up. The can-do girls are "optimistic, self-inventing, and success-oriented", while the at-risk girls are "living in poverty, in unstable homes, in communities known for violence, drugs, and crime" (Harris 2004:24).

References to the trope of 'can-do' and 'atrisk' girls are often used in the fourth agenda item that this paper will expand on: girls' reproductive rights and choice. The training of the 'can-do girls' generates the ideal worker/consumer/citizens who are independent and capable of taking care of their own lives in most Global North societies. This ideal figure also often delays their childbearing and/or child rearing duties because of their successful careers. In contrast, at-risk girls are seen as 'problematic' individuals who often fall to the trap of teen pregnancy and child or early marriage. Young motherhood, in other words, is a "calamity" (Duncan 2007:307) and an "unthinkable waste and a tragedy" (Harris 2004:23). The discourse of reproductive rights and choice as it is 'transferred' to the Global South girls, however, takes a different form. The right and choice to delay motherhood and pregnancy are promoted by NGOs to countries like Indonesia as a form of 'empowerment' and population control that can help alleviate poverty and social issues (Horii 2019). So, while it is framed as reproductive rights and choice, it is also about fulfilling the demand for Global South young women's entry to and intensification of their role in the labour force. This does not really address the global and structural inequalities between the Global North and the Global South (Hickel 2014).

Literature on critical perspectives on child marriage is still very limited. Bunting (2005) emphasizes that the portrayal of child marriage as universal throughout the world and the human rights argument that hones in the analysis of child marriage practices ignore the context of structural problems at the global level. To elaborate on the problems of dominant child marriage discourse, Belen Giaquinta (2016) analyzed the problems using post-development theory, post-colonial feminism, and the new sociology of childhood studies frameworks as explained below.

Firstly, as a geopolitical agenda in the practice of global mainstream development (MacKinnon 2011), child marriage is often seen as a problem experienced by Third Nations or Third World, although in practice it occurs in Western countries as well, such as the United States and the United Kingdom (Gangoli, McCarry, and Razak 2009; Warner 2004). In addition, when child marriage is framed as a 'Third World problem', not all areas of the Third World are represented equally. Child marriage as a global issue is often represented through 'hot spot' areas, referring to places where intervention is necessary, or where the practice occurs (Giaquinta 2016). In other words, borrowing Arturo Escobar's (1995) perspective, in an effort to problematize a social reality, patriarchy and ethnocentrism play a role in silencing the voices of those who should define their own problems. 'Colonization of reality', according to Escobar, plays the role of forming the dominant discourse when the representation of certain groups becomes dominant and shapes perceptions of social reality. Monocultural assumptions that arise related to child marriage are then considered and used as a dominant development framework, which are not in accordance with the reality that occurs in many contexts.

Secondly, post-colonial feminism, according to Giaquinta (2016), considers that the position of women and girls in mainstream child marriage discourse is constructed as monolithic and 'Other' subjects. The lens of post-colonial feminism is thus useful to dismantle the representation of dominant 
women and girls in the global discourse of child marriage, specifically how discourse constructed by Western countries is used in describing women's experiences, a practice of the 'appropriation of knowledge', borrowing from Chandra Tapalde Mohanty (1988). This has uprooted women's and girls' experiences from various forms of oppression that are influenced by the political, historical, socio-cultural contexts of women, including the power structures at work. In addition, narratives of young people's sexuality--an aspect that is closely related to the issue of child marriage--are often ignored or excessively regulated in mainstream global discourse. Girls' sexual subjectivity is neglected in understanding their agency to marriage, or it is corrected to follow the categorization of good and bad sexual experiences through development interventions.

Finally, the development of critical studies of childhood plays an important role in dismantling the problem of the dominant global discourse of child marriage, especially in relation to the universalized understanding of childhood. A human rights-based approach that is used popularly as a framework for development interventions often places girls as nonsexual, passive, vulnerable, and in constant need for protection from adults (Bhana 2008; Giaquinta 2016). Although child participation is used as one of the key strategies in preventing child marriage in Indonesia, participation is limited to prevent child marriage practices (Bappenas \& KPPPA 2020). This limits further attempts to investigate children's own decision to marry, including to examine carefully relational and situational aspects that help shape their decision (Horii 2020). In the contradiction between child agency and sexuality, Waites (2005:19) asks: "[W]hat, then, are the conditions in which children should be called to participate in decision making, and give their 'consent' in activities affecting them?". Moreover, many critical thinkers have argued that the global definition of children, agreed internationally through the Convention on the Rights of the Child, was formed based on the single imagination of Western society towards an ideal childhood, which was then imported as a universal model of childhood throughout the world through development interventions (Ansell 2005).

\section{METHODS}

To understand how the discourse around Global South and Indonesian girls and child marriage develops, we deployed discourse tracing as an analytical method. Discourse tracing refers to the analysis of "the formation, interpretation, and appropriation of discursive practices" (LeGreco and Tracy 2009: 1518). To do so, we traced the history around child marriage in Indonesia from previous research. We also find patterns on the depiction of girls and child marriage in six publicly available reports as listed in Table 1.

The six documents selected were publicly accessible reports in the past 5 years that included Indonesia in their analysis. These reports were produced by international NGOs who are active in promoting children, youth, and girls' wellbeing through their program and advocacy. We understand that the documents do not cover the breadth of reports published by international NGOs on child marriage in Indonesia, and it is not the goal of the current study to map them out. Our focus, rather, is to understand how the lives of Indonesian girls specifically and the 'Global South' girls generally have been imagined in different ways in relation to the problem of child marriage in order to push forward the project of decolonizing our knowledge production about the girls (Saraswati and Beta 2020). Below, we profile the NGOs and the documents included in this study.

Plan International was founded in 1937 in Spain, and today it is working in 75 countries around the globe. Plan's The 2020 Asia Girls Report: Introducing the Asia Girls' Leadership Index (2020) (hereafter Asia Girls Report) and Time to Act! Accelerating Efforts to Eliminate Child, Early and Forced Marriage in Asia (2018) (hereafter Time to Act) analyzed in this study were published by Plan International Asia Hub based in Bangkok, Thailand. Asia Girls Report is the NGO's "inaugural research report on the situation of girls in Asia and part of our contribution to the sustainable development agenda" (2020:9). While the report admits 
the speedy rise of Asian economies, it claims that "[i] nequality in Asia looks different than in other parts of the world" to justify its introduction of Asia girls' leadership index. The index includes six key components (education, economic opportunity, protection, health, political voice and representation, and laws and policies) and 23 indicators. The index is used to measure the girls' leadership in 19 countries in Asia. In almost each of the components measured, Singapore--the richest country included--leads the index. It is perhaps not a surprise since countries in East Asia such as Japan, China, Taiwan, Hong Kong, and South Korea are not measured in this index. This report focuses on five countries for profiling in the report, which included an extensive discussion of the lives of the girls and child marriage in Bangladesh, India, Cambodia, Indonesia, and Vietnam.

Save the Children (Save) was founded in 1919 in the United Kingdom. Save's Every Last Girl (2016) is the second installment of the organization's Every Last Child series. The report provides a global overview of child marriage cases and highlights the results of Girls' Opportunity Index measured for 144 countries. Countries listed as the lowest ranked are mostly those in Africa and the Middle East, while Indonesia is in the 73rd position. Save's Toward an End to Child Marriage: Lesson from Research and Practice in Development and Humanitarian Sectors (2018) (Toward an End) provides a global overview by synthesizing previous literature, mapping Save's previous intervention programmes on child marriage around the globe and including practitioners' voices.
Rutgers is a Netherland-based centre on sexual and reproductive health and rights which today operates in 18 countries founded in 2010. Rutgers' Lembar Fakta Kesetaraan Gender Remaja di Indonesia or Gender Equality Fact Sheet for Adolescents in Indonesia (2019) (Fact Sheet) and Gender Norms and Adolescent Development, Health and Wellbeing in Indonesia (2019) (Gender Norms) provide an overview of gender equality, and report gender socialization and sexuality development in Indonesia among 12-24 year olds sourced from the organizations' Explore4Action research and advocacy program.

This paper approaches the reports, policy documents, books, articles, and news as integral part of the discourse of child marriage. Following Chandra Tapalde Mohanty, we use the lens of 'feminist solidarity' that focuses "not just on the intersections of race, class, gender, nation, and sexuality in different communities of women but on mutuality and coimplication", which "requires understanding the historical and experiential specificities and differences of women's lives as well as the historical and experiential connections between women from different national, racial, and cultural communities" (2003:242). This means that our discourse tracing of child marriage and Indonesian girls is informed with the belief that girls and young women in different societies and cultural contexts have different experiences. This approach allows us to be mindful and critical when encountering generalizing and global outlooks on how girls should live and should be supported. The following two sections discuss our findings.

Tabel 1.

Overview of Recent Reports Published by International NGOs Analysed in This Study

\begin{tabular}{|c|c|c|c|c|}
\hline No & Organization Name & Report Title & $\begin{array}{l}\text { Publica- } \\
\text { tion year }\end{array}$ & $\begin{array}{c}\text { Countries the report } \\
\text { focuses on }\end{array}$ \\
\hline 1 & Plan International (Plan) & $\begin{array}{l}\text { The } 2020 \text { Asia Girls } \\
\text { Report: Introducing the } \\
\text { Asia Girls' Leadership } \\
\text { Index }\end{array}$ & 2020 & $\begin{array}{ll}\text { Regional (Asia) } \\
\text { 1. } & \text { Afghanistan } \\
\text { 2. } & \text { Pakistan } \\
\text { 3. } & \text { India } \\
\text { 4. } & \text { Nepal } \\
5 . & \text { Bhutan }\end{array}$ \\
\hline
\end{tabular}




\begin{tabular}{|c|c|c|c|c|}
\hline & & & & $\begin{array}{ll}\text { 6. } & \text { Myanmar } \\
\text { 7. } & \text { Bangladesh } \\
\text { 8. } & \text { Sri Lanka } \\
\text { 9. } & \text { Maldives } \\
\text { 10. } & \text { Thailand } \\
\text { 11. } & \text { Cambodia } \\
\text { 12. } & \text { Vietnam } \\
\text { 13. } & \text { Lao PDR } \\
\text { 14. } & \text { Philippines } \\
\text { 15. } & \text { Malaysia } \\
\text { 16. } & \text { Singapore } \\
\text { 17. } & \text { Brunei Darussalam } \\
\text { 18. } & \text { Indonesia } \\
\text { 19. } & \text { Timor Leste }\end{array}$ \\
\hline 2. & Plan International (Plan) & $\begin{array}{l}\text { Time to Act! Accelerat- } \\
\text { ing Efforts to Eliminate } \\
\text { Child, Early and Forced } \\
\text { Marriage in Asia }\end{array}$ & 2018 & \begin{tabular}{ll}
\multicolumn{2}{l}{ Regional (Asia) } \\
1. & Bangladesh \\
2. & India \\
3. & Cambodia \\
4. & Indonesia \\
5. & Vietnam
\end{tabular} \\
\hline 3. & Save the Children (Save) & Every Last Girl & 2016 & $\begin{array}{l}\text { Global overview, including } \\
\text { Indonesia }\end{array}$ \\
\hline 4. & $\begin{array}{l}\text { Save the Children \& UC } \\
\text { Berkeley School of Law } \\
\text { Human Rights Center } \\
\text { (Save) }\end{array}$ & $\begin{array}{l}\text { Toward an End to Child } \\
\text { Marriage: Lesson from } \\
\text { Research and Practice } \\
\text { in Development and } \\
\text { Humanitarian Sectors }\end{array}$ & 2018 & Global overview \\
\hline 5. & $\begin{array}{l}\text { Global Early Adolescent } \\
\text { Study \& Rutgers WPF } \\
\text { (Rutgers) }\end{array}$ & $\begin{array}{l}\text { Lembar Fakta Kese- } \\
\text { taraan Gender Remaja } \\
\text { di Indonesia }\end{array}$ & 2019 & Indonesia \\
\hline 6. & $\begin{array}{l}\text { Global Early Adolescent } \\
\text { Study, Youth Voices Re- } \\
\text { search, \& Rutgers WPF } \\
\text { (Rutgers) }\end{array}$ & $\begin{array}{l}\text { Gender Norms and Ad- } \\
\text { olescent Development, } \\
\text { Health and Wellbeing in } \\
\text { Indonesia }\end{array}$ & 2019 & Indonesia \\
\hline
\end{tabular}


A HISTORICAL OVERVIEW OF CHILD MARRIAGE ADVOGAGY IN INDONESIA

On 14 October 2019, Indonesian President Joko Widodo signed Law Number 16 of 2019 on the Amendment to Law Number 1 of 1974 on Marriage. This new law raised the minimum age of marriage to 19 years old for both boys and girls, a change from 16 years old for girls and 19 for boys in the 1974 Law. This was followed by the Indonesian government's ambitious goal to reduce the rate of child marriage by 2030 , as outlined in the recently launched National Strategy for the Prevention of Child Marriage (Bappenas \& KPPPA 2020). The National Strategy is carried out to meet Indonesia's National Development Planning goals to improve the quality of human capital. UNICEF reported that Indonesia is one among the ten highest countries in the world (UNICEF \& Bappenas 2019). According to National Census Bureau (BPS) data in 2018, 1 in 9 girls aged 20-24 married before the age of 18 (BPS, Bappenas, UNICEF \& PUSKAPA 2020).

The agenda to eliminate child marriage, particularly to increase the minimum age of marriage for girls has been debated by various elites in the twentieth century of Indonesia. In their article "The Debate on Child Marriage from the Colonial Era", Sita Thamar van Bemmelen and Mies Grijns (2018) argue that child marriage should be understood as a political issue, as it has been debated and often divided Muslim conservatives and the modern elite. This was documented through the archives from the beginning of the Dutch occupation in Indonesia, the early period of Indonesian Independence, up to today's political climate. Van Bemmelen and Grijns' article highlights that political elites from certain social class, ethnicity, affiliation to certain religious beliefs and organizations become the dominant group that shapes the discourse of child marriage in Indonesia since the colonial period to the present. In the $\mathrm{co}^{-}$ lonial era, particularly in the first two decades after 1900 , there was a common understanding between the Javanese and Sundanese elite, the aristocrats (priyayi) men, their educated wives, and the Dutch colonial government that child marriage was considered as a practice that has to be eliminated. The $\mathrm{co}^{-}$ lonial government went further by implementing various policies to tackle child marriage but this effort received backlash from urban reformist organizations as well as traditional clerics in rural areas who held tight local customs. This was seen as an effort to counter the legitimacy of custom-based colonial powers (Huis 2015: 79). This refusal rolled over to Muslim organizations and political parties on a more massive scale which later led to the debate over the minimum age of marriage in 1973. The New Order government originally proposed 18 years old for women and 21 years old for men. However, the agreement that many parties accepted was 16 years old for women and 19 years old for men.

The idea of modernizing Indonesia also fuels the arguments of those who advocate for the elimination of child marriage. In the early twentieth century of Indonesia, Blackburn and Bessell (1997) found that according to the elite social reformers, the practice of parents marrying off their daughters at or before the onset of puberty was considered a 'social evil'. Before this century, only few Indonesians knew their precise chronological age due to the lack of birth registration, and marriage itself was regulated under the supervision of kin and religious (particularly Islamic) authorities (1997: 108). The idea of modernization, through the promotion of individual rights and the state's control over family life was brought initially by the Dutch colony in their attempt to problematize child marriage as a political and morality issue that needed to be intervened.

The lack of rigorous data was also proven to be a challenge when it comes to advocating for the elimination of child marriage in the early twentieth century of Indonesia. However, although child marriage was defined differently in many communities, anecdotal evidence made it clear that child marriage was a common practice occurring in various social classes across the archipelago. The attempt to increase the minimum age of marriage was too intimately interlinked with religious and customary law, which was proven to ignite too many disagreements particularly from strong Islamic networks.

Child marriage agenda, particularly regulating the minimum age of marriage for girls, is best under- 
stood in the context of broader policy objectives, particularly in the New Order regime of authoritarian Indonesia. This is particularly relevant in the context of regulating the age of marriage after 1965. The enactment of Marriage Law in 1974 was part of the state's control over population growth, human capital development through education, as well as regulating the domestic roles of women, followed by the depoliticization of the women's movement (Blackburn and Bessell 1997: 136). According to van Bemmelen and Grijns (2018), after Reformasi in 1998, there has been a proliferation of new actors in child marriage advocacy, with child-focused organizations came into the scene in their attempt to promote child welfare and survival. The popularisation of the ideal notion of childhood, through the adoption of the Convention on the Rights of the Child (CRC) as a development framework since the early 1990s marks the new era of regulating Indonesian childhood. The focus on girls, has become popular among international humanitarian organizations, where child marriage becomes one pertinent issue that needs saving.

Various studies have shown the role of young people's agency as an important aspect in determining with whom, when, and why marriages occur. Several case study research in Bali and West Java found that in many cases, young people were the ones who made the decision to get married, and in their perspective, their marriage is not considered as forced marriage (Horii 2020; Grijns et al. 2016). Moreover, Grijns et al (2016) identify a typology of child marriages in West Java based on young people's agency, firstly are love matches of young people who chose their own partners as well as marriages inspired by orthodox beliefs. Similarly, an ethnographic research in Lombok also shows the use of social media in challenging social norms related to early marriage, as social media facilitates the possibility of young people to find a partner, engage in premarital sex, and marriage (Termeulen 2019). With the 'universal' definition of child marriage as any type of (forced) marriages under the of 18 , child marriage has become a discursive practice that remains to be uncontested and unchallenged (Horii 2020). What we propose is instead to acknowledge the diversity of this practice as well as young people's agency, especially girls, in making decisions about their own marriage. To further our investigation, the next sections discussed the findings based on international NGOs reports published in the past five years. We found three key patterns: the persistence of humanitarian visuality depicting the imagined sufferings of Indonesian and Global South girls; the emphasis on the girls' community problems; and the constant calls for investment.

\section{IMAGINING SUFFERINGS}

We will start with the most obvious pattern that emerged from our analysis: the persistent visual stereotypes of girls in Asia. A number of studies have looked into the persistence of the visuality of the brown/black/poor girl in development discourses. There is presumed universality of the Global South girls suffering, eliding "differences of race, nation, and class" (Khoja-Moolji 2016). The work of Fuyuki Kurusawa on humanitarian visuality is key here. He aptly argues that "humanitarianism, like other large political and socio-economic apparatuses, must actively construct objects and sites for their intervention (i.e., events and situations of mass disaster, scenes and states of emergency, and conditions of victimhood, suffering, and trauma,) and corresponding subjects (i.e., vulnerable, victimized and suffering populations, predominantly of colour and in the global South)" (2015:2-3). The construction of girls as the 'corresponding subjects' through images, therefore, should not be treated as secondary to the textual discourses in the documents. In each of the reports we analyzed here, we can clearly see the role of the images to help its readers imagine the lives of the girls. Further, the images help the justification for different forms of intervention programs campaigned in the reports. In other words, "[the] pictures create the space for human rights politics and the humanitarian imaginary" (Kurasawa 2015:4)

The images accompanying the reports on child marriage analyzed in this study are filled with girls with brown or darker complexion. Most of them are portrayed alone, with the camera focusing on one girl, usually looking back at the camera. 
They may be smiling or looking serious.

In some images, when she is not alone, people behind her are blurred. The individual girl often stands in front of an earthly coloured background or she stands outside a rather dirty looking environment. In a number of images, the girl is also wearing the veil, suggesting her Islamic identity. When the girls in this report are portrayed in groups, which only appear in a few pages, most of them are accompanied by girls of similar complexion. A naive question could be asked: Is the problem of child marriage only experienced by girls of certain characteristics?

The problem of child marriage has been constructed as a social problem faced by girls in different countries around the world, including in developed countries. Nevertheless, the 'cultural backwardness' linked to the child marriage as a social problem in the reports is represented by the images of girls with darker complexions, in sites that signify poverty. Images of brown/black girls standing alone are repeated to conjure a sense of pity for the suffering of girls living with the 'threat' of child marriage. Their bodies, in other words, represent a space justifiable for humanitarian intervention in developing nations.

The second pattern emergent from the reports is the tendency for the NGOs to demonstrate how the girls are living in exceptionally problematic circumstances because of the oppressive community and social norms they live in. The main causes of the girls 'suffering' are the families, the communities, and the norms the girls had to live in. The reports made by Plan and Save sweep through different cultures and societies and make quick generalizations and then claim that, because of the oppressive environment they live in, the girls have no power over their own lives.

Plan's Asia Girls Report best exemplifies how the lives of girls in Asia are reduced and flattened out. "In many parts of Asia, girls and women are undervalued, underestimated, and continue to encounter gender-related restrictions and inequalities that keep them from realising their full potential" (2020:12). The report frames the lives of the girls in Asia in binary: either they grow up with the interven- tions of the NGO and therefore become successful or they fail in life because they live in communities in which child marriage is common and will therefore end their education and their career. In this report, a successful future for girls in Asia can only be achieved when the girls are equipped with leadership capabilities so that they can earn leadership roles in businesses and government institutions. The report continues its claim:

"If a girl is to develop those capabilities, her family and community must first address inequalities and their detrimental impact to her health, nutrition and education. She must be supported and encouraged to make her own decisions and to pursue opportunities that will allow her to realise her own goals, including those related to her career, whether or not she marries, and if and when she will have children. She must be given the same opportunities as her male peers to participate in public discourse, hold decision-making roles, and be protected from discrimination, harass ment and abuse." (2020:15)

The claim quoted above demonstrates how for international NGOs like Plan, the fault is located in the family and the community. The imagined social units in Asia are seen here to be ahistorical, static, and generalizable across the region, and child marriage is seen to be a prevalent social problem because the girls live in such communities which are innately unequal: "Girls often face gender discrimination before they are even born, due to attitudes and behaviour patterns passed down from generation to generation" (2020:16). In Plan's Time to Act, specific ethnicities are framed as to have a higher prevalence of child marriage: "Child marriage rates are highest in rural areas and in West Sulawesi, with some evidence that CEFM [Child, Early, and Forced Marriage] may be higher among specific ethnic groups including the Sundanese in West Java and Madurese in East" (2018:13). Even in reports that use global perspective such as Save's, stories of girls used in the reports came from those living in 'Global South' countries. Save's Every Last Girl (2016) cites stories of girls from Ethiopia, El Savador, and the Philippines to demonstrate girls' suffering. In each story, the community is depicted to be oppressive and violent. 
We are not proposing that we should deny actual social violence and problems. Child marriage can be problematic and exploitative. However, we propose that by framing certain communities or societies as inherently and exceptionally problematic, the international NGOs maintain the marginalization of girls from the Global South by depicting them as victims. Gender and sexual inequalities are not specific to Global South nations; however, the constant derision of the girls' cultures, communities, and societies leaves little to cover up the international NGOs neo imperialist framework. The absence of extensive discussions about the cultural problems or stories of sufferings of girls from 'developed' nations in East Asia in Plan's Asia Girls Report, for instance, demonstrates the epistemic injustice of how Asia girls should be imagined and known. Interventions to kinship and gender roles in Global South should not be taken as self-evident (Hickel 2014) nor should it be allowed to be vague or generalized. We should be critical, and perhaps a bit more cynical, with claims that generalize and transplant the same model of suffering for girls who live in vastly different circumstances.

The third and last emergent pattern we would like to focus on is related to the ways in which the reports employ the girls' imagined oppressed and backward lives for calls for investment. The word investment is mentioned frequently in the documents we analyzed. The logic is that funds funneled by developed countries and rich donors will fix the future of the girls, lift them up from poverty, and protect them from the threat of child marriage.

The justification for demands for investment is made by using girls as 'emblems of futurity', (MacDonald 2016:13). One of the claims made in Plan's Asia Girls Report demonstrate this:

"Access to education shapes the outcomes of individuals from the earliest stages of their life. Educating women and girls has immense potential for the development of children and adolescents themselves, as well as for their future children. Education promotes social inclusion, supports economic growth and increases gender equality by reducing socio-economic disparities and delaying marriage and pregnancy. In- contrast, a lack of education reduces employment opportunities and future earning capacities that, over time, contribute to income inequality and lead to continued cycles of poverty." (2020:33)

The quote above demonstrates the two paths set up for girls. The first is a life filled with educational opportunities which facilitate social mobility and gender empowerment. The second one is a path that leads the girls to a series of failures due to lack of education. In other words, NGOs like Plan have mapped out and predicted the futures of the girls, and following the binary logic, deviations from the ideals they set up is assumed as failure. How then should the NGOs guarantee the predicted future of the girls? Save's Every Last Girls explains that

"[t]ackling the root causes of girls' exclusion and disempowerment is not easy - that's an understatement. But with sustained effort and investment, change is possible. It is possible to build a world that guarantees the equal rights and freedom for every last girl to fulfil their potential. This requires working to support the empowerment of every last girl, while simultaneously working with stakeholders at all levels, including men and boys, to enable environments where girls can realise their full and equal rights and thrive" (2016:vii).

Even in a report that focuses on Indonesia, Rutgers' Gender Norms stake their demands for change using the language of 'investment': "We must make use of the window of opportunity that early adolescence presents and invest in very young adolescents to build positive and equitable gender norms" (2019:6).

While donations and funds can practically help the lives of the girls, the NGO reports do not provide space for serious discussions of global economic inequality that may cause the precarious and insecure lives the girls live in nor do they explain how child marriage may provide a false sense of security for the girls and their families precisely because of the "global economic and political forces that impoverish women (and men) in the global South in the first place" (Hickel 2014:1364). While one could argue that this has been a social 'script' that NGOs follow or that in many circumstances different discourses have made girls or females bear 
the responsibilities of social problems, we refuse to accept the impossibility of changing the discourses about Global South girls.

\section{GONCLUDING NOTES: INDONESIAN AND GLOBAL SOUTH GIRLS BEYOND VICTIM- IZATION}

Through our analysis, we aim to showcase that the child marriage discourse, as we trace historically, is rooted in specific colonial ideas surrounding modernity, childhood, and marriage. The debates around child marriage needs to be understood in the context of broader policy objectives in different periods. At present time, we show how international NGO documents have tendencies to flatten the complex experience and lives of Indonesian girls into forms of victimization sourced from the girls' problematic communities.

While the dominant child marriage discourse as a violation of human rights continues to be unchallenged and uncontested (Horii 2019), we argue on the importance to investigate child marriage practices critically. From our analysis, we show that the universalistic and ahistorical portrayal of girls only continues to justify the need of international development interventions and that it misses the complete and diverse factors that drive child marriages, including the agency of young people.

Moving forward, future empirical research on child marriage needs to investigate the contextualized realities of this practice, including to put the focus on investigating young people's sexualities and the agency of young people in determining with whom, when, and how marriage occurs (see Colquhoun and Nilan 2020 in this edition). Through this, as informed by previous research in Indonesia (see Horii 2019, 2020; Grijns and Horii 2018), future social policies can offer a range of alternatives in addressing the harmful impacts of child marriage beyond regulating the minimum age as envisaged by the dominant discourse. By focusing on banning child marriage, social policies obscure the diverse social realities, tend to drive the practices underground (see Boyden et. al. 2012; Archambault 2011), and serving its empowering role. As Bunting argues, "early marriage is a symptom not a cause of the socio-economic troubles facing many adolescents in developing countries" (2005:34).

As child marriage has become an emerging development agenda at the global and national level, we hope that this paper would also serve as a call for academics and policy makers to reinvestigate and address our own biases and limitations of our knowledge on how we analyze problems that we wish to tackle. Our hope is that this paper contributes to ignite future conversations around development narratives, interventions, and Indonesian and Global South girls, especially on the importance of different representations that value girls' resilience, capabilities, and complexities.

\section{NOTES}

${ }^{1}$ It is important to note that the idea of 'girl' and 'girlhood' here should be understood first as an 'assemblage of social and cultural issues and questions rather than a field of physical facts' (Driscoll 2008). That said, in international development discourse, girls usually refer to those aged 15-24 years. Girls involved in child marriages are usually those aged under 18 years old.

\section{ACKNOWLEDGEMENT}

We would like to thank Wina Aprilia Tirtapradja for her assistance and Marissa Saraswati for her advice and insights. 


\section{REFERENCES}

Ansell, Nicola. 2005. Children, Youth, and Development. Oxon: Routledge.

Archambault, Caroline S. 2011 "Ethnographic Empathy and the Social Context of Rights: "Rescuing" Maasai Girls from Early Marriage", American Anthropologist, Vol. 113, No. 4 pp. 632-643

Banet-Weiser, Sarah. 2015. "Confidence You Can Carry!': Girls in Crisis and the Market for Girls' Empowerment Organizations." Continuum 29(2):182-93.

Bappenas \& KPPPA. 2020. Strategi Nasional Pencegahan Perkawinan Anak (National Strategy for the Prevention of Child Marriage). Jakarta: Ministry of Planning and Ministry of Women Empowerment and Child Protection.

Bhana, Deevia. 2008. "Children's Sexual Rights in an Era of HIV/AIDS." Pp. 77-85 in Development with a Body: Sexuality, human rights and development, edited by A. Cornwall, S. Corrêa, and S. Jolly. London \& New York: Zed Books.

Blackburn, S. \& Bessel, S. 1997. "Marriageable Age: Political Debate on Early Marriage in Twentieth-century Indonesia”. Indonesia, 107141

BPS, Bappenas, UNICEF Indonesia, \& PUSKAPA. 2020. Pencegahan Perkawinan Anak: Percepatan yang Tidak Bisa Ditunda.Jakarta: National Statistics Bureau and Ministry of Planning.

Bunting, Annie. 2005. "Stages of Development: Marriage of Girls and Teens as an International Human Rights Issue." Social \& Legal Studies 14(1):17-38.

Colquhoun, Lisa., and Pamela Nilan. 2020. "Early Marriage among Sasak Boys in Rural North Lombok". Jurnal Studi Pemuda, Vol 9 (2). doi: 10.22146/studipemudaugm.56370
Calkin, Sydney. 2015a. "Feminism, Interrupted? Gender and Development in the Era of 'Smart Economics.'” Progress in Development Studies 15(4):295-307.

Calkin, Sydney. 2015b. "Post-Feminist Spectatorship and the Girl Effect:'Go Ahead, Really Imagine Her."' Third World Quarterly 36(4):654-669.

Cobbett, Mary. 2014. "Beyond 'Victims' and 'Heroines': Constructing 'Girlhood' in International Development." Progress in Development Studies 14(4):309-20.

Duncan, Simon. 2007. "What's the Problem with Teenage Parents? And What's the Problem with Policy?" Critical Social Policy 27(3):307-334.

Driscoll, Catherine. 2008. "Girls today-Girls, Girl Culture and Girl Studies." Girlhood Studies 1(1):13-32.

Escobar, Arturo. 1995. Encountering Development: The Making and Unmaking of the Third World. Princeton: Princeton University Press.

Gangoli, Geetanjali, Melanie McCarry, and Amina Razak. 2009. "Child Marriage or Forced Marriage? South Asian Communities in North East England." Children \& Society 23(6):418-429.

Giaquinta, Belèn. 2016. "Silenced Subjectivities \& Missed Representations: Unpacking The Gaps Of The International Child Marriage Discourse." MA Thesis. International Institute of Social Studies, The Hague.

Global Early Adolescent Study \& Rutgers WPF. 2019. Lembar Fakta Kesetaraan Gender Remaja Di Indonesia.

Global Early Adolescent Study, Youth Voices Research, \& Rutgers WPF. 2019. Gender Norms and Adolescent Development, Health and Wellbeing in Indonesia. 
Grijns, M., Limijaya, S., Agustinah, A., Restuningrum, N., Fathurrohman, I., Damayanti, V. \& Harahap, R. 2016. "Pernikahan Anak di Sukabumi Jawa Barat: Diri dan Agensi Anak Perempuan” Jurnal Perempuan 88, 21 (1), 9-33

Grijns, Mies., and Hoko Horii. 2018. "Child Marriage in a Village in West Java (Indonesia): Compromises between Legal Obligations and Religious Concerns". Asian Journal of Law and Society, 5(2), 453-466

Harris, Anita. 2004. Future Girl: Young Women in the Twenty-First Century. London: Routledge.

Hickel, Jason. 2014. "The 'Girl Effect': Liberalism, Empowerment and the Contradictions of Development." Third World Quarterly 35(8):1355-73.

Horii, Hoko. 2019. "A Blind Spot in International Human Rights Framework: a Space Between Tradition and Modernity within The Child Marriage Discourse?", The International Journal of Human Rights

Horii, Hoko. 2020. "Walking a thin line: Taking Children's Decision to Marry Seriously?", Childhood: a global journal of child research 27(2): 254-270.

Huis, S.C. van. 2015. "Islamic Courts and Women's Divorce in Indonesia: The cases of Cianjur and Bulukumba". Ph.D. thesis. Leiden: Leiden University.

Khoja-Moolji, Shenila. 2016. "Representations Matter: It Is Critical to Deconstruct the Narratives and Visuals of Development Campaigns."SouthAsia@LSE.

Koffman, Ofra, and Rosalind Gill. 2013. "The Revolution Will Be Led by a 12-Year-Old Girl: Girl Power and Global Biopolitics." Feminist Review 105(1):83-102.

Kurasawa, Fuyuki. 2015. "How Does Humanitarian Visuality Work? A Conceptual Toolkit for a Sociology of Iconic Suffering." Sociologica 9(1):1-59.

LeGreco, Marianne, and Sarah J. Tracy. 2009. "Discourse Tracing as Qualitative Practice:" Qualitative Inquiry.
MacDonald, Katie. 2016. "Calls for Educating Girls in the Third World: Futurity, Girls and the "Third World Woman.'” Gender, Place \& Culture 23(1):1-17.

MacKinnon, K. 2011. "Development Professionals in Northern Thailand". Singapore: National University of Singapore Press (1-21).

Mohanty, Chandra Tapalde. 1988. "Under Western Eyes: Feminist Scholarship and Colonial Discourses." Feminist Review 30(1):61-88.

Mohanty, Chandra Talpade. 2003. Feminism Without Borders: Decolonizing Theory, Practicing Solidarity. Durham: Duke University Press.

Plan International. 2018. Time to Act! Accelerating Efforts to End Child, Early and Forced Marriage in Asia. Bangkok.

Plan International. 2020. The 2020 Asia Girls Report: Introducing The Asia Girls' Leadership Index. Bangkok.

Saraswati, Marissa, and Annisa R. Beta. 2020. "Knowing Responsibly: Decolonizing Knowledge Production of Indonesian Girlhood." Feminist Media Studies 0(0):1-17.

Save The Children International. 2016. Every Last Girl: Free to Live, Free to Learn, Free from Harm. London.

Save The Children International \& The Human Rights Center at the University of California, Berkeley, School of Law. 2018. Toward an End to Child Marriage: Lessons from Research and Practice in Development and Humanitarian Sectors.

Termeulen, Renske R. 2019. "Love, sex, and marrying early in Lombok, Indonesia: Researching young people's agency and the influence of social media". MSc. Thesis. Amsterdam: University of Amsterdam.

UNICEF \& Bappenas. 2019. Achieving the SDGs for Children in Indonesia: Emerging Findings for Reaching the Targets. Jakarta: Ministry of Planning and UNICEF 
Van Bemmelen, S. T. \& M Grijns. 2018. "Perdebatan tentang Perkawinan Anak, Mulai dari Zaman Kolonial Hingga ke Kurun Jawa Masa Kini: Adat, Agama, dan Negara" in Menikah Muda di Indonesia: Suara, Hukum, Praktik, p. 321-372. Jakarta: Yayasan Pustaka Obor Indonesia.

Waites, Matthew. 2005. The Age of Consent: Young People, Sexuality, and Citizenship.New York: Springer.

Warner, Elizabeth. 2004. "Behind the Wedding Veil: Child Marriage as a Form of Trafficking in Girls." American University Journal of Gender, Social Policy \& the Law 12(2):23372.

Wilson, Kalpana. 2015. "Towards a Radical Re-Appropriation: Gender, Development and $\mathrm{Neo}^{-}$ liberal Feminism." Development and Change 46(4):803-32. 